\title{
(i) $\Theta(0$ \\ Miseducation in South African public schooling: The case of To kill a mockingbird
}

\author{
Lindiwe Maqutu - University of KwaZulu-Natal \\ Adrian Bellengere - University of KwaZulu-Natal
}

\section{Abstract}

Journal of Decolonising Disciplines Volume 2, Issue 2 (2020) eISSN: 2664-3405

DOI: https://doi.org/10.35293/jdd.v2i2.21

A racial incident revolving around the teaching of To kill a mockingbird in a South African school has prompted this examination of how set works are implicated in the disseminating of race-related beliefs. The way the book is taught, it is argued, cements the continuation of the alienation of blackness by affirming ubiquitous white normativity. It perpetuates the notion that the fault lies in an 'existential deviation' that inheres in black people. This examination highlights how, through the purposive propagation of white normality, the book exhibits anti-black sentiments. The sympathetic white psyche that subsists simultaneously with the continuing enjoyment of racial favouritism is appraised. The stance of the book is confronted by noting the contrived, largely absent voices of black people in the narrative. This book positions the black characters as props for the absolution of the white protagonists (and, by proxy, sympathetic white people) during circumstances of the unremitting and deadly racial oppression. 


\section{Introduction}

'To us, the man who adores the Negro is as "sick" as the man who abominates him.

(Fanon [1952]/1986: 10)

In recent times, former white South African schools have had reports of incidences of racism as well as accusations of the upkeep of racially problematic norms. This piece highlights a particular alleged incident in a KwaZulu-Natal public high school (the KZN School), which should prompt interrogation of the possibility that set works may be implicated in the moulding of South African school children to accept indefensible race-related beliefs. ${ }^{1}$ The incident centred on the teaching of the book To kill a mockingbird by Harper Lee to grade 10 English pupils. This well-known novel, which gives a fictional account of events set in the 1930s American South, has been celebrated as an important text which elucidates the cruelty of racism perpetrated on blacks during American segregation. This article posits that the status of the text as a seminal teaching tool for understanding and interrogating white supremacy and the racism it engenders (and the excuses it offers) is somewhat flawed. The pedestal on which the book has stood is disputed, with particular reference to the South African milieu.

The most obvious shortcoming rests on the fact that the novel, written by a white woman who places herself in the position of a child narrator, explores its chosen

1 A classroom discussion on To kill a mockingbird led a white teacher to express her view on the contemporary debate surrounding land expropriation without compensation in South Africa, disavowing its validity. The teacher was reported to have 'drawn similarities' between the events of the book and what she saw as the plight of white South African landowners. This culminated in her impassioned racial 'rant', during which she was described as out of control and wherein she referred to her black students in the classroom, as well as African people in general, as 'kaffirs'. See J Wicks. (2018, 28 August). English Teacher Accused of K-word Rant. Time Live. https://www. timeslive.co.za/news/south-africa/2018-08-28-english-teacher-accused-of-k-word-rant/; Citizen reporter. (2018, 28 August). Yet another K-word kerfuffle as high school teacher resigns. The Citizen. https://citizen.co.za/news/south-africa/2001524/yet-another-k-word-kerfuffle-as-high-school-teacher-resigns/; T Broughton. (2018, 30 August). 'I am not a racist' says teacher accused of K-word rant. Times Live. https://www.timeslive.co.za/news/south-africa/2018-08-30-i-am-not-racist-says-teacher-accused-of-k-word-rant/. 
subject matter from an unashamedly white perspective. ${ }^{2}$ In so doing, the novel affirms the ubiquitous white normativity, a problematic position that does not adequately explore the quandary of a juxtaposed black alienation, both in the text and within societal relations. The voice/s of the disparaged sufferers of a racially segregated Jim Crow American South are by and large muted, only to be explained from time to time through the apparent innocence of the protagonist - a white prepubescent girl. This article contends and illustrates that, quite apart from the gross distortion and the manner in which it took place in the KZN School incident, the manner in which the text has been interpreted and the manner in which this interpretation has been disseminated requires scrutiny in order to forestall damaging inroads into children's education. After all, what is included in a curriculum influences 'who we perceive ourselves to be' - in other words, race, text and identity are interrelated concepts (Castenell \& Pinar 1993: 60). This may seem trite, but if one of the foundational concepts in this triumvirate of identity-formation is disfigured, the risk of establishing skewed racial identities increases, especially since, as Pinar states, 'racial representation ... portrays, suppresses and reformulates racial identity'

To kill a mockingbird recounts the unjust accusation, trial and conviction of a black man, Tom Robinson, of the rape of a white woman. The book became and remains a popular fictional account of race inequality and racism, wherein a black man is charged with raping a white woman and is defended by a white man, Atticus Finch. This 'Holy Grail among English teachers' (Milburn 2001: 90) reveals Atticus as a quintessential 'image of racial heroism' (Crespino 2000: 10). The novel is often seen as depicting the limits of justice for marginalised black people while teaching integrity through the conduct and sentiments of the white protagonist. Atticus famously states: 'You never really understand a person until you consider things from his point of view - until you climb into his skin and walk around in it' (Lee 1960: 33). This article interrogates, from the preponderance of perspective in the account, whose 'skin' Lee (the author and therefore the book) inhabits and considers worthy of articulation and credence.

2 There are other problematic issues, not least of which is that the novel was written in the 1950s and is thus imbued with events and attitudes prevalent at the time of its creation. Although arguable that the author was able to represent the 1930s uninfluenced by such events and attitudes, this is belied somewhat by the fact that the Emmet Till trial of the 1955 provided the blueprint for, or at least exerted an influence on, Tom Robinson's trial. See P. Chura. (2000). Prolepsis and anachronism: Emmett Till and the historicity of To kill a mockingbird. The Southern Literary Journal, 32(2): 1-26. 


\section{Reinforcing white normality and marginalising blackness in school instruction}

'The school and university as they currently exist in South Africa were founded by the European settler' (Dladla 2017a) '[as] nurseries for nurturing a westernized black intellectual aristocracy.' (Mazrui 1997)

Colonial and imperialist European aspirations brought white settlers to South Africa. An ideology that imbued indigenous Africans with subhuman traits and transfigured settlers as masters ordered the manner of violent subjugation which followed. In the colonial context, racism is a central component - 'the highest expression of colonialism' (Louw 2017: 5). 1994 ushered in a 'not-so-new' South African situation that left the renowned systemic maltreatment of the blacks unrecompensed (Dladla 2017a: 227). The spectre of conceited British conquest along with the delusion of ordained Afrikaners' dominion (over Africans) lingers in the South African milieu (Lephakga 2013; Said 1986). So, notwithstanding professed seismic legal and philosophical shifts marking the changeover to the post-apartheid era, the inadequately acknowledged yet pervasive tentacles of whiteness (exemplified in adherence to Eurocentrism and evident white advantage) still hold sway. Notions of dignity and equality for the majority of South Africans may remain indefinitely hollow so long as they continue to be measured and judged by and according to the prescripts of whiteness.

Leonardo (2002: 34) describes a western mainstreamed 'pedagogy of amnesia'; here, colonial atrocity is buried or obscured by a preoccupation with valorising conquest (Ramose 2002). Whiteness, being 'not only a position of privilege but synonymous with hegemony' (Kaunda 2017: 4), legitimates and normalises the racial socio-economic, cultural and political inequalities in society. Beneficiaries and other auxiliary facilitators avoid confronting whiteness and its hierarchical ordering of things, and the reality that 'many of the privileges that flow to Whites are invisible, unearned, and not consciously acknowledged' (Picower 2009: 198). Dladla describes a 'continued commitment to ignorance [coupled with] ... an overall commitment to continue along the colonial lines of mimesis' (Dladla 2017a: 208). In this way, charges of racism are presented as dubious manifest envy from underachievers who begrudge the bounty of their industrious counterparts (Leonardo 2002).

Contrary to assertions of liberation and progress toward equivalence, even nowadays, white norms continue their ascendancy in South Africa. Dladla (2017a) 
describes a duplicitous liberal culture, where whites claim to reject white sovereignty while continuing to enjoy it fully (Memmi 1974). The contradictory position of sympathetic whites who appropriate the adversity of Africans and then have the impudence to seek to articulate it typifies whiteness in operation. However sincere the commiseration, actually inhabiting blackness is anathema to whiteness. Biko aptly asks, '[b]lack souls in white skins?' (Biko [1978]/1987: 19-20; Dolamo 2017: 3), referring to such empathetic expressions resting on a belief in the rightful stewardship by whites of deficient black people. Biko argued that, as integral members of the oppressive hegemony, whites could and would pursue only minimal cosmetic revisions. Black people would allow this hijacking of narrative because 'blacks are suffering from inferiority complex' (Biko [1978]/1987: 21). Du Bois argued that black people were afflicted with double consciousness, 'a sense of always looking at one's self through the eyes of others' (Du Bois 1903). The damaged selfperception of colonised people is a much-explored theme by Fanon, who stated that ' $\mathrm{t}$ ] he colonised is elevated above his justice status in proportion to his adoption of the [colonising] country's cultural standards. He becomes whiter as he renounces his blackness, his jungle' (Fanon [1952]/1986: 18).

hooks explains that the subliminal message (supported by reality) to black people is 'that the world is more a home for white folks than it is for anyone else, [therefore] black people who most resemble white folks will live better in that world' (hooks 1996: 31; Lopez 2005).

Fanon's ([1952]/1986) metaphor Black skin, white masks 'creates a dual process of mimicry: when the mask fits, appearances are counterfeited on both sides' (Sandoval 2000: 83-84); a splintered consciousness is created, where the capacity for release or escape is held back by the inability to confront the persistent oppression. Therefore, Fanon asserted 'that what is called the black soul is a white man's artifact', because impaired awareness directs how and what we (blacks and whites) see and experience as real (Fanon [1952]/1986: 16). Sandoval describes 'dominant social reality as an interested construction, ... distorted mirrors, ... constructed "artifacts" of a dominating race, sex, and gender politics' (Sandoval 2000: 86). Part of the pathology of self-denial and self-deception of black people has been explained by processes of surveillance integral to accepting Eurocentric normalcy. The infiltration of black social thought and compliance to subjection has meant that disquiet could not be expressed even among black people, leading to incessant (outward and inward) selfcensorship (Ikard 2013). The result is a warped discernment in many black people, 
who have been 'conditioned to experience white supremacy as normalcy [along with an] obsession with proving their humanity to whites' (Ikard 2013: 11; Morrison 1987). So the exploits of whiteness are inextricably linked to a fabricated blackness and its continued acquiescence and lack of independent agency, which might otherwise disrupt whiteness. In South Africa, it is all the more important that peoples and structures that benefit from racial inequity be intercepted from obscuring its continued historical and current relevance through influential literary storytelling that favours whiteness.

Morrison (1992) has cogently illustrated how, in literary narratives, white cultural frames relegate depictions of black identity, culture and experience along with the politics connected thereto to being all but invisible. In reality, ' $[t]$ he world does not become faceless or will not become unracialized by assertion'; therefore, avoiding the interrogation of racially problematic norms in literature 'is itself a racial act' (Morrison 1992: 46). Since pervasive present-day modes of thinking and behaviour render whiteness unseen (Dass 2017), 'whitely assumptions' seem to permeate legitimised discourse (Vice 2010: 326). Morrison (1989: 13) identifies deliberate absences in literary narrative, 'absences' that 'are so stressed they arrest us with their intentionality and purpose'. It behoves the reader to ask: '[w] here is the shadow of the presence from which the text has fled?' (Morrison 1989: 14).

In some respects, the KZN School, being a former white-only public school during the apartheid era of mandatorily segregated education, has historically been a site for the propagation of an established white ascendancy - through legalised indoctrination. In this setting, the objective of discussion would be to convince white people of the merits of rejecting racism - as defined by their own readily apparent orthodoxy (Bery 2014). Bery (2014: 334) is critical of schemes 'deployed by Whites to address and eliminate racism', which in fact, 'in the absence of collective struggles to dismantle the apparatus of white supremacy', tend to reinforce the mainstreamed racist hegemony displayed in less obvious forms - reproducing white supremacy. The self-declared non-racialism or colour-blindness of these projects, which ignores the disadvantaged position of blacks, dodges challenging the institutionalised phenomena (Modiri 2011). The failure to acknowledge and actively seek to dismantle the ideology which governs the racial status quo leads to white supremacy continuing to be perceptible in basic education tutelage. The personal lived experiences and beliefs of teachers and their students are the filters through which a presented 'reality' will come to be understood (Leonardo 2013: 600). Therefore, '[o]bjective reality 
carries different meanings for racialized subjects, depending on their social location without determining those meanings' (Leonardo 2013: 600). The instructing position or conceptual framework regarding race needs to be clarified: racism as a systemic edifice not construed merely as 'expressions of individual prejudice' (Leonardo 2013: 599).

\section{To kill a mockingbird as a teaching tool: A validation of whiteness?}

'What I propose here is to examine the impact of notions of racial hierarchy, racial exclusion, and racial vulnerability and availability on nonblacks who held, resisted, explored, or altered those notions.' (Morrison 1992: 10)

Racism also impairs the white psyche, distorting understandings of equality, humanity, justice, oppression, bigotry and compassion. While some resist, others accept the norms it instils. In line with the recommendation of Morrison (1992), scholars have explored how a double consciousness also manifests in white people. White double consciousness, an examination of the sympathetic white psyche, has three major components, namely: conflict between public and private images as a result of power relations between the individual and the group; professed moral values or good intentions coupled with accommodation of racial injustice; and sustained genuine struggle for righteousness, which is hindered by nostalgia for the status quo (Ntusi 2015). Similar to the US experience, racism so grounds South African society 'that it constitutes the bedrock of whiteness and white privilege' (Ntusi 2015: 2; Feagin 2010). Therefore, 'white double consciousness is a tension between the white subject's calculating move of claiming possession of the best moral and cultural values, and his realisation that "the lowly" ones know about his pretension and resist it' (Ntusi 2015: 14; Baldwin ([1965]/1988).

Ntusi (2015) remarks that the purpose of the book was to instil the notion that, regardless of patent discriminatory injustices faced by black people, some white folk could be so committed to being virtuous as to put themselves at risk trying to help blacks. Ako-Adjei (2017: 198) bluntly states that '[n]o book, I think, captures this constitution of white innocence and the reimagining of history better than To kill a mockingbird'. The touchstone theme in the book is that of identifying the virtuous white man, whose character seems to transcend the matrix of the rampant racism in which he operates. So the question that pertains to the relevance of the text is 
whether it should be read as a spectacular rendition of white absolution.

The disquieting message of the novel is that the structural iniquity may be eclipsed through an isolated exhibition of moral courage (Lee 1960). Yet Atticus exercises courageousness, which has been forged within and is performed circumscribed by the confines of the racist society from which he draws privilege. The credo, neither strained nor threatened in the book, remains the source of logic. Following the conviction of Tom Robinson, Miss Maudie attests that the trial process was 'a baby step, but ... a step' in the right direction on the part of the Maycomb community (Lee 1960: 237-238). Nonetheless, it appears that part of Atticus' fortitude is based on turning a blind eye to the terrorism of his white counterparts and friends perpetrated against black people; he brands the Ku Klux Klan as merely 'a political organisation more than anything' (Lee 1960: 161). In this, Lee redacts applicable historical and contemporaneous realities of the American South, making this account palatable for herself and her readers.

According to a 2015 Equal Justice Initiative Report, upwards of 4075 black people were killed through lynching, a brutal method of public murder, between 1877 and 1950. ${ }^{3}$ These horrific spectacles aimed at terrorising and subduing blacks in America (particularly in the South) were essentially condoned through inaction and some measure of endorsement by state and federal law enforcement. Hamilton (1977) recounts that, routinely in Alabama, the precipitating cause was an accusation of rape of a white woman by a black man. Yet in chapter 15 of the novel a possible lynching is thwarted by the child narrator Scout, who comes to the rescue of Tom Robinson (who was to be lynched by the white Maycomb mob), while Atticus looks on. These and other portrayals of the historic American segregation era promote a false memory of what actually often occurred. Apart from validating the sugar-coating of the ruinous 'racial and economic hierarchy of small-town life' during the 1930s, the sanitised experience centres almost entirely on the purveyors of discrimination - white people (Pearson 2018: 320). In so doing, Lee minimises the pervasive dehumanisation of Africans wrought by operationalising such political ideologies. The author accomplishes this shrewd manipulation by ostensibly interpreting the machinations through the precocious innocence of the children - Scout, Jem and Dill. Any misapprehension on the part of Atticus may, perhaps conveniently and

3 Equal Justice Initiative Report. (2015). Lynching in America: Confronting the Legacy of Racial Terror. https://eji.org/reports/lynching-in-america. 
indulgently, be attributed to safeguarding the innocence of the children.

Importantly, Pride (2002: 19) points out that while real-life events matter, literary recounts 'are perceptual filters that we use to make sense of [the] world'. Accounts of what happened decode what we take out of specific events. For stories to find acceptance, they must cohere with value systems and align with the foundational myths of a people' (Pride 2002: 20). Therefore, in this context, a metanarrative that 'spoke for Africans and their descendants, or of them' proved useful (Morrison 1992: 50). In this construction, there could be no intelligible reply from the African, as such (possibly vexed) dialogue risked the intrusion of a counter-narrative. Ward (1994) describes 'projective empathy' conceived from an individualistic liberal paradigm which projects one's own circumstances, race, gender and other biases to the engagement - thus blocking real empathy with a non-similarly situated other (Delgado 1996: 71). Inevitably, the oppression of blacks, with its attendant fractured consciousness, has prompted the embrace of this counterfeit empathy as real.

At no time does Atticus, or indeed Lee, appear to attempt to consider the unfolding events from Tom's perspective. The notion here is that there is noblesse oblige - white altruism - which ameliorates the hopelessness and incapacity of the black populace in the book. The tale reinvents whites as 'saviors rather than oppressors of other races [with blacks depicted as] passive or ineffectual victims who cannot save themselves' (Moore \& Pierce 2007: 183). Such narratives re-package white supremacy by inculcating the 'notion of whiteness as good, civilised, and just' (Moore \& Pierce 2007: 183). They re-programme the collective memory and cast benevolent white men as stewards of the emancipation of black people from racial subjugation. A tale of white innocence is thus conceived.

It allows white people in the present day to disclaim complicity in the generalised downtrodden position of blacks. In order to do this, black people are conceived devoid of their lived (social and economic) realities, effectively concealing the abasement of their 'humanness' - black abstraction (Ross 1990: 6). In order for white innocence to gain traction through black abstraction, a partial narrative, conceptualised through white eyes, is constructed. The world as seen and experienced by black people is rendered dispensable and remains unrecognised. The ubiquitous normalcy created around what is in effect a white point of view bears scrutiny in the post-apartheid context because many of our educational cannons rest on these Eurocentric norms. Morrison (1992: 12) argues that persisting in the mantra 'that literature is not only "universal" but also "race-free" risks lobotomising that literature, and diminishes 
both the art and the artist'. It is necessary in the current South African epoch to deconstruct the ideological position along with the potency of instruction contained in To kill a mockingbird, particularly as a tool to confront and begin to examine the way racism impairs its white perpetrators and custodians. Vera, Feagin and Gordon (1995) contend that the warped nature of prejudice includes broad self-deception as a comparator to the denigrated other. An essential component 'to understanding white racism is to be found not only in what whites think of Africans ... other [races] ... but also in what whites think of themselves' (Feagin, Vera \& Batur 2001: 5).

Freire (1970: 51) observed that '[f]unctionally, oppression is domesticating'. It subdues both tormentor and tormented, causing all to accept the disparities as indisputable and warranted (Freire 1970). 'Sincere fictions' are concocted to obscure continual misbehaviour, rooted in the past, within white society based on racist apprehensions (Vera, Feagin \& Gordon 1995: 297). They are 'sincere' because apart from being communally endorsed, 'actors usually are genuine and honest in their adherence to these rationalisations ... of the events or people being fictionalised' (Vera, Feagin \& Gordon 1995: 278; Bourdieu 1989).

What is undeniably apparent from the above is that, whether one agrees with it or not, there exists an extremely powerful discourse around the role of literature in reinforcing the notion of white double consciousness and programmed white empathy. It is also clear that To kill a mockingbird, in many respects, is an exemplar of such literature. As such, its role as a useful pedagogical tool in illustrating this discourse cannot be overlooked. It is an example of how sugar-coated white complicity in racial subjugation side-steps the imperative to propagate and thereby participate in establishing racial equality. The 'feel-good' factor it generates is based squarely on the principles of othering, 'privilege' and 'amnesia' (or at the very least trivialising) about the plight of black people. Therefore, the novel still has relevance in the classroom, but not for the reasons for which it is presently being used.

\section{Confronting the white positionality in the book}

A critique of white normativity in literature requires an interrogation of the following (Morrison 1992: 52-53):

- how the black character is a prop (an object) against which the white imaginings materialise; 
- how black representations highlight and legitimate white normalcy; and

- the usurpation and perversion of the black voice as an intercession for whiteness.

Van Patten (2016) deliberates on a deep-seated commitment by the racially privileged to palatable fictitious portraits, which prevents an unmitigated exploration of systemic cruelty. In order to sway its audience, the narration of a story is rooted in a delineated, often familiar, 'moral infrastructure' (Van Patten 2012: 244). Perhaps far from establishing the moral superiority of the book, the widespread popularity of To kill a mockingbird within mainstream discourse in societies that have innate (historically established) racially dysfunctional norms warrants deep interrogation. Foundational to South Africa is the legitimised socio-political and economic propagation of white supremacy through law and other measures, education being key (Ndimande 2013; Nkomo 1990). Therefore, the question remains: which lingering 'whitely' attitudes would induce South African audiences to respond to the palliative ministrations of the book? Would a more probing critical reflection repair the educative value of the book? A brief critical summation of the literary portrayal of Atticus Finch and Tom Robinson is thus made with these questions in mind.

\section{Atticus Finch}

The discrimination exemplified by racial segregation is the social and legal concourse within which Atticus resides and plies his trade. While he apparently imperils his good name and safety in a community faithful to an ingrained racial aversion which extolls white supremacy - it is worth noting that the moral compass of Atticus does not lead him to seek to reject the flawed system and agitate for either sociopolitical or legal changes in his community or indeed the American South. As a legislator and a lawyer, he is already an important and influential member of this community. He does not stand resolutely apart from his community but instead has been integral in shaping its continued leanings. His manner has been described as one seeking to accommodate the racism, instead of reforming it (Lubet 1999). He is in reality a product of his environment, presumably as good as it can get under the circumstances. However much Atticus Finch may be thought to wish things were different, as part of the Maycomb elite he can and appears to have in fact chosen to remain somewhat impervious to the degradation that racism inflicts on the Negros. 
The South African reader should be cautious about being persuaded by the author of the supposed good morals and intentions of Atticus Finch, remaining ever vigilant of the harm that pervasive racial bigotry causes to the psyche of white people (such as Lee). The indictment of the book by Ako-Adjei (2017: 198) as a construction of 'white innocence' which reimagines history bears noting when evaluating its underlying message. Such an exploration may help to dispel the narrative claims of possessing 'the best moral and cultural values' so integral to white double consciousness, by instead seeking the recount of unwavering factual counter-narratives emanating from "the lowly" ones' - the occluded Negro perspective (Ntusi 2015: 14; Baldwin ([1965]/1988).

Atticus Finch downplays the ferociousness and influence of the Ku Klux Klan, which he describes as 'a political organisation more than anything else' which 'couldn't find anybody to scare' and which was easily dispatched by Sam Levy's reprimand (Lee 1960: 161-162). He describes Cunningham, who led the mob hoping to kill Tom Robinson, as 'basically a good man' with 'blind spots along with the rest of us' (Lee 1960: 173). Freedman (1994: 476) reproves the interpretation thus: '[i]t just happens that Cunningham's blind spot (along with the rest of us?) is a homicidal hatred of black people'. Atticus appears to absolve Cunningham of responsibility because he was acting as part of a group. Freedman (1994) denounces the relativism which attributes malleable morality, specific to circumstances such as lynching and apartheid - making room for valuations based on prejudicial norms. In this regard, the lived experience of black people in Maycomb would be pertinent to the tale - the metaphoric climbing into their 'skin', as recommended by Atticus Finch in relation to his bigoted white counterparts. From this vantage, there surely can be no equivocation about the degrading, Jim Crow-legitimated apartheid of Alabama during this time (the 1930s). In reality, the questionable morality of the Maycomb community ensured that the die was cast on the fate of Tom Robinson well before the farcical procedural motions of the trial. The merciless killing of Tom Robinson (during an attempted escape) appears to be almost inevitable - his bullet-riddled body is a testament to his ghastly situation. In such a society, 'Tom was a dead man the minute Mayella Ewell opened her mouth and screamed' (Lee 1960: 266).

Atticus Finch attributes the diminution and maltreatment of Negros euphemistically to the communal disease of Maycomb. Yet this apparent dearth of stark moral introspection has been prized as noble racial progressivism. Atticus Finch worries about his children being infected with 'Maycomb's usual disease', 
which foregrounds the inevitability of Tom's fate (Lee 1960: 243). Notwithstanding the indignities and cruelty this white psychosis occasions on Negros, the remedy for the madness appears to be found solely in the conduct of Atticus Finch. This plays out in various ways, including in the next chapter (Lee 1960: 98-109), where Calpurnia points out the rabid dog to Atticus and some of the other white townspeople. It is Atticus Finch who saves the day, while Sheriff Tate hesitates. Ironically, this very pillar of white supremacy (a legislator and lawyer) is cast as saving the Negros from its extremes. A hateful, abusive alcoholic and possible sexual predator who attacks children, Bob Ewell stands as the perfect screen for the comparably unobtrusive brutality of southern racism in 1930s Alabama (Ako-Adjei 2017). Resignation is evident when Atticus Finch remarks (regarding Tom Robins), '... that boy might go to the chair, but he's not going till the truth's told.... And you know what the truth is' (Lee 1960: 161).

Perhaps the genius of the book is that Atticus Finch validates a patently unfair society with racially deplorable norms as well as its judicial process (through his robust defence of Tom), well-knowing that the result is a foregone conclusion, and in the process, he acquires heroic status. The lesson the book seems to be portraying is that, without rocking the system, one can, and should, do the morally right thing, to no significant effect - in fact, one can fail so completely that an innocent man is killed - and emerge a hero. Is this the lesson that To kill a mockingbird is being used to teach? If so, it is being put to woefully deficient use. Atticus is a validator of an unjust and unequal society, not a fully-fledged and honest hero, and a failure to make this point is to miss an opportunity to teach the necessity of fighting for systemic change. His disposition is good, even exemplary, but only in comparison to his bigoted community. In truth, the sentiments of the prospective lynch mob represent the obscured real heart of the Maycomb community.

The question of what constitutes a reliable measure of good morals is where the true value of using this book as a teaching aid in a South African context lies. A privileged school like the one in question should interrogate this or at least recognise that there exists a debate about whether to use a flawed system in an attempt to do some good, as Atticus did, or to fight to change the system as a whole. The complexity of this debate should resonate in South African schools, communities and in the country as a whole, where systemic injustice is still prevalent. The novel is ideally placed to shed some light on the debate. Students and other readers of the book need to know it is not enough for the average white South African to aspire to be an 
Atticus. Tom Robinson was a cause for which Atticus was propelled or even prepared to fight, but putting an end to systemic racism in the South barely registered in his consciousness (Lee 1960).

\section{Tom Robinson, Lula and black subjectivity}

The characterisation of the black Tom Robinson, in lowly juxtaposition to that of Atticus Finch, evokes the sentiments expressed by Fanon, namely:

In the white world the man of color encounters difficulties in the development of his bodily schema ... What else could it be for me but an amputation, an excision, a haemorrhage that spattered my whole body with black blood? (Fanon [1952]/1986: 110,112)

The detailed narration of Tom Robinson's physical disposition in the book sets a particularly defeating and telling tone.

He looked oddly off balance, but it was not from the way he was standing. His left arm was fully twelve inches shorter than his right, and hung dead at his side. It ended in a small shriveled hand ... I could see that it was no use to him. (Lee 1960: 205, 209-210)

He is obviously physically handicapped, and the book's narrative proceeds to reveal his internalised submission to white supremacy as well - the quintessential tolerable black temperament. One wonders whether this depiction is the only way Lee (the author) could persuade the readers (not just the Maycomb community) that this Negro could not have committed the crime. Pitted against the flawed evidence of the complainant and other white witnesses, would an able-bodied and defiant black man have personified guilt? Would a display of rehabilitated dignity, which could trigger black truculence in the face of subordination, also be anathema to the current South African mindset?

The image of the cowed, powerless black man in the form of Tom Robinson accords with the novel's philosophy on what constitutes an acceptable Negro, contrasted with the aggression of Lula (Lee 1960). Lula is denounced as 'a troublemaker from way back, got fancy ideas an' haughty ways' (Lee 1960: 132). Her hostility and refusal 
to show expected submissive behaviour toward white children destabilises the form of the novel and stands out as a blight in the otherwise idyllic white fantasies of the book. One is left to speculate on Lula's motivation. Was she perhaps expressing fear of retribution from the white community for having had these children in a designated black space? The spectre of lynching for the slightest infraction loomed large for blacks at the time. That a black congregant would not be permitted in a white church remains an unaddressed given in the text. Did Lula's belief in 'fancy ideas' perhaps entail (to an extent) rejecting the normalised subjugation of blacks, and did she feel safer expressing her resentment in the presence of the children? Maybe not, given the prevailing racial realities of the time and the overall scheme of the book. Pearson (2018: 326) remarks that '[t]he idea that blacks might resent, even loathe,' whites along with their diminished status 'is almost unimaginable' in the novel.

While much is made, even speculatively, of the internal musings of the white characters, a Negro such as Tom Robinson remains an object, inducing expressions of confusion, rage, racial contempt, guilt and redemption for the white characters in the book. It is the 'turmoil' of Atticus Finch, his children and other white people that the book coaxes the reader to become immersed in, instead of the more pressing life-threatening situation being faced by Tom Robinson (Pearson 2018: 327). This then validates a normalcy in the debased position of the Negro, which the events of the book display. The potential embitterment of the white children is contemplated probably because that of the Negros appears unfathomable. Indeed, on being found guilty, Tom Robinson is reputed (by Atticus Finch) to have given up and attempted to flee, rather than being angered by a criminal conviction he did not deserve. From the perspective of the book, one is persuaded to believe that the white characters who suffer somewhat as a consequence of the unsuccessful defence of the hapless Tom Robinson are thereby exempted from their complicity in the degradation of Negros (Pearson 2018). In a way, the book fosters the impression that these hardships are comparable to the obscured lived reality of the Negro existence or make up for their continued subjugation, or at least the unjust treatment which leads to the killing of Tom Robinson.

Lula represents the most authentic black character created by Lee in the novel. In Lula's attitude, Lee affords us a glimpse of a strong and defiant response to humiliation, degradation and living life balanced on the knife-edge of uncertainty and immediate 
threat. ${ }^{4}$ It is one of anger, pride and defiance tinged with perhaps some fear. One of the more widely available study aids in South Africa, the X-Kit Achieve literature study guide: To kill a mockingbird (Gosher, Gosher \& Hendry 2016), references the character Lula as a tool used by Lee to show that Negros are racist. On page 5, under the headings 'Prejudice and racism' and 'Back versus white', Lula is described as 'hostile', and on page 25 she is described as 'making racist comments about Scout and Jem' Given the overall content and structure of the book, the propagation of this dubious conclusion by the X-Kit study guide is disturbing. Lula's attitude, far from showing that 'blacks are racists' as was claimed in the KZN School in question as well as in the widely used X-Kit study guide, is in fact likely an exemplar of a plausible response in the circumstances. The voice of Lula stands out as an instance of authenticity in the narrative of the novel. It illustrates that defiance or anger are expected in the face of injustice. By contrast, following Tom's conviction, the display of gratitude to Atticus by black people, in the form of offerings of food, is a notable indicator of their muzzled voices in the narrative (Lee 1960). This and the scene which saw them earlier rising in coloured balcony for Atticus (Lee 1960) signal the essence of the book's appeal - the 'readers' desires to be white saviors' (Ako-Adjei 2017: 185); or indeed to be rescued by a fabled white benevolence.

\section{The book as a teaching tool}

Lee's book is steeped in white ascendancy, to which the black people in the novel neatly submit. This supposedly fitting submission is, for the book, the hallmark of the quintessential acceptable Negro, and it is in accord with this maxim that Atticus Finch accomplishes his feats (Atkinson 1999). Tom Robinson, a physically handicapped Negro who 'knows his place', is for the novel and its readership 'a model black man' - deserving of the protagonist's valiance (Atkinson 1999: 622, 626). According to Nietzsche, 'there exists, strictly speaking, neither an unegoistic action nor completely disinterested contemplation; both are only sublimations, in which the basic element seems almost to have dispersed and reveals itself only under the most painstaking observation' (Reginster 2000: 180).

Thus, the outward upright selflessness of Atticus Finch requires examination. The

4 The novel is unclear as to whether Lula is angered at the invasion of a black (church) space by white children or afraid of the consequences if white children were to be found in their company. 
institutionalised racial inequality, so normalised in the text, creates the ideal backdrop for the much-touted progressive intervention of Atticus to mitigate its obvious excesses. For an impressionable (predominantly black) South African audience, the notion of passive black people in need of white stewardship and protection presents a disconcerting portrayal. It has the potential to obscure the post-apartheid imperative to disrupt the colonially contrived dysfunctions within and between black and white racial understandings. More so because the socio-economic setup in South Africa appears, by and large, to validate the primacy of white people vis-à-vis their black counterparts (Gravett 2017). For South Africa, the reputation of the book, which does not appear to fathom the necessity of black agency, as an indispensable tool or step toward physical and mental emancipation is at odds with the historical and present-day lived experience of non-whites.

Therefore, a pivot which acknowledges that the book proffers events and their evaluation from a perspective which decidedly draws minimally and superficially from a marginalised black experience ought to found a South African reading. These deliberate absences should 'arrest us with their intentionality and purpose' (Morrison 1989: 13). Ndimande (2013) endorses education which illuminates the existing imbalances and manifest subjugation. This 'social justice' education entails the development of the ability of persons to critically evaluate material and situations, so as 'to understand oppression and their own socialisation within oppressive systems, and to develop a sense of agency and capacity to interrupt and change oppressive patterns' (Ndimande 2013: 21; Bell 2007).

Clearly, To kill a mockingbird achieves the aim of illuminating existing imbalances and manifest subjugation to a certain extent - or does it? The imbalances are downplayed, subordinated in fact, to the feel-good storyline and are thus not so much illuminated as obscured, while the manifest subjugation is reinforced, not undermined, by the choice of protagonist. But can it still be used to show white and black students alike how they have been socialised into an oppressive system? Perhaps, but not if it is used in the manner in which it is presently deployed. The way it was referenced in the KZN classroom was a gross distortion, which does not emanate from the text. Yet it is notable that the book does not even attempt to show that whites should not be racist. Therefore, the mute acceptance of the pervasive white racism underlying the novel should be focal in studying the novel. This book certainly should not be used in formal instruction, in endeavours to show that 'blacks are racist too'. This kind of opinion serves to embolden the downplaying 
of the destructiveness of Jim Crow America on black people and allow for grossly misplaced analogies, as evinced by the teacher at the KZN School in question.

\section{Conclusion}

Recent experiences in the KZN School and others have highlighted some matters. Regarding the curriculum:

- The choice of what text to include in a given curriculum is a charged and complex one and has not been approached with the foresight and broadened intellectual acuity necessary.

- The manner in which a text is used can have fundamentally differing consequences on how it is understood, depending on the narrative that it is chosen to support, which itself is acutely dependent on the views and attitudes of the teacher and/or the curriculum.

Regarding To kill a mockingbird:

- The image of the subjugated black person is still being perpetuated in education with the effect of creating a culture of acquiescence which, inter alia, results in stifling the development of psychological emancipation from racial oppression and of critical reflection on its past and present manifestations.

- This novel should still be taught as a critical reflection on the ubiquity of white normativity in literature and society and as an example of just how easy it is to twist text to suit a selected narrative. It is rich with scenes and themes that are deeply rooted in a horrific historical context.

To kill a mockingbird can be a potent teaching tool, not despite its shortcomings but precisely because of them. It has already generated much debate and exhibits many subconscious attitudes worthy of examination. It is well placed to illustrate prejudice, not merely in the manner envisaged by Lee, but also to show the dangers inherent in the one-sided appropriation of narrative. 


\section{References}

Ako-Adjei, N. (2017). Why it's time schools stopped teaching To kill a mockingbird. Transition, 122: 182-200.

Atkinson, R. (1999). Liberating lawyers: Divergent parallels in Intruder in the dust and To kill a mockingbird. Duke Law Journal, 49(3): 601-748.

Baldwin, J. ([1965]/1988). The white man's guilt. In T. Morrison (Ed.), Collected essays. Library of America.

Bell, L. (2007). Theoretical foundations for social justice education. In M. Adams, L. Bell \& P. Griffin (Eds), Teaching for diversity and social justice (pp. 1-14). New York: Routledge.

Bery, S. (2014). Multiculturalism, teaching slavery, and white supremacy. Equity \& Excellence in Education, 47(3): 334-352.

Biko, S. ([1978]/1987). I write what I like: Selected writings: Steve Biko, edited by A. Stubbs C. R. Chicago: Chicago University Press.

Bourdieu, P. (1989). Social space and symbolic power. Social Theory, 7(1): 14-25.

Broughton, T. (2018, 30 August). 'I am not a racist' says teacher accused of K-word rant. Times Live. Retrieved from https://www.timeslive.co.za/news/southafrica/2018-08-30-i-am-not-racist-says-teacher-accused-of-k-word-rant/

Castenell, L.A. \& Pinar, W.F. (Eds). (1993). Understanding curriculum as a racial text: Representations of identity and difference in education. Albany: State University of New York Press.

Chura, P. (2000). Prolepsis and anachronism: Emmett Till and the historicity of To kill a mockingbird. The Southern Literary Journal, 32(2): 1-26.

Citizen reporter. (2018, 28 August). Yet another K-word kerfuffle as high school teacher resigns. The Citizen. Retrieved from https://citizen.co.za/news/southafrica/2001524/yet-another-k-word-kerfuffle-as-high-school-teacher-resigns/

Crespino, J. (2000). The strange career of Atticus Finch. Southern Cultures, 6(2): 9-30.

Dass, M. (2017). 'Wishy-washy liberalism' and 'the art of getting lost' in Ivan Vladislavićs Double negative. English in Africa, 44(3): 9-30.

Delgado, R. (1996). Rodrigo's eleventh chronicle: Empathy and false empathy. California Law Review, 84(1): 61-100.

Dladla, N. (2017a). Racism and the marginality of African philosophy in South Africa. Phronimon, 18: 204-231. 
Dladla, N. (2017b). Towards an African critical philosophy of race: Ubuntu as a hilopraxis of liberation. Journal of Philosophy, Culture and Religions, 6(1): 39-68.

Dolamo, R. (2017). The legacy of Black Consciousness: Its continued relevance for democratic South Africa and its significance for theological education. Theological Studies, 73(3): 1-7. DOI:10.4102/hts.v73i3.4587

Du Bois, W. (1903). The souls of black folk. Chicago: A. C. McClurg \& Co.

Equal Justice Initiative Report. (2015) Lynching in America: Confronting the Legacy of Racial Terror. Retrieved from https://eji.org/reports/lynching-in-america

Fanon, F. ([1952]/1986). Black skin, white masks translated by C.L. Markman 1986. London: Pluto Press.

Feagin, J. (2010). The white racial frame. New York: Routledge.

Feagin, J., Vera, H. \& Batur, P. (2001). White racism: The basics. New York: Routledge. Freedman, M. (1994). Atticus Finch - right and wrong. Alabama Law Review, 45(2): 473-482.

Freire, P. (1970). Pedagogy of the oppressed. New York: Continuum.

Gosher, S., Gosher, B. \& Hendry, J.O. (2016). X-Kit Achieve literature study guide: To kill a mockingbird. Cape Town: Pearson.

Gravett, W. (2017). The myth of objectivity: Implicit racial bias and the law (Part 1).

Potchefstroom Electronic Law Journal, 20: 1-25. Retrieved from

Hamilton, V. (1977). Alabama: A bicentennial history. W. W. Norton \& Co.

hooks, b. (1996). Bone black: Memories of girlhood. New York: Henry Holt \& Co.

Ikard, D. (2013). Blinded by the whites: Why race still matters in 21-century America. Indiana University Press.

Kaunda, C.J. (2017). Hijacking Subaltern's history (broken bodies broken voices): Decolonial critique of 'Subaltern whiteness' in South Africa. Theological Studies, 73(3): 1-9. DOI:10.4102/hts.v73i3.4619

Lee, H. (1960). To kill a mockingbird. London: Random House.

Leonardo, Z. (2002). The souls of white folk: Critical pedagogy, whiteness studies, and globalisation discourse. Race Ethnicity and Education, 5(1): 29-50.

Leonardo, Z. (2013). The story of schooling: Critical race theory and the educational racial contract. Studies in the Cultural Politics of Education, 34(4): 599-610.

Lephakga, T. (2013). The history of the theologized politics of South Africa the 1913 Land Act and its impact on the flight from the black self. Studia Historiae Ecclesiasticae, 39(2): 379-400. 
Lopez, A. (2005). Introduction: Whiteness after empire. In A. Lopez (Ed.), Postcolonial whiteness: A critical reader on race and empire (pp. 1-30). Albany: State University of New York Press.

Louw, D. (2017). 'Black pain is a white commodity': Moving beyond postcolonial theory in practical theology: \#CaesarMustFall! Theological Studies, 73(4): 1-14. DOI:10.4102/hts.v73i4.4504

Lubet, S. (1999). Reconstructing Atticus Finch. Michigan Law Review, 97(6): 13391362.

Mazrui, A. (1997). The star-spangled dialectic: African universities and the model of higher education. The International Journal of African Studies, 1(1): 1-21.

Memmi, A. (1974). The colonizer and the colonized. London: Souvenir Press.

Milburn, M. (2001). Lighting the flame: Teaching high school students to love not loathe literature. The English Journal, 91(2): 90-95.

Modiri, J. (2011). The grey line in-between the rainbow: (re)thinking and (re)taking critical race theory in post-apartheid legal and social discourse. South African Public Law: 177-202.

Moore, W. \& Pierce, J. (2007). Still killing mockingbirds: Narratives of race and innocence in Hollywood's depiction of the white messiah lawyer. Qualitative Sociology Review, 3(2): 171-187.

Morrison, T. (1989). Unspeakable things unspoken: The Afro-American presence in American literature. Michigan Quarterly Review, 28(1): 1-34.

Morrison, T. (1987). Beloved. New York: Alfred A. Knopf, Inc.

Morrison, T. (1992). Playing in the dark: Whiteness and the literary imagination. Harvard University Press.

Ndimande, B. (2013). From Bantu education to the fight for socially just education. Equity \& Excellence in Education, 46(1): 20-35.

Nkomo, M. (Ed.). (1990). Pedagogy of domination: Toward a democratic education in South Africa. Trenton: Africa World Press.

Ntusi, J. (2015). White double consciousness in Lilian Smith's Strange fruit, Harper Lee's To kill a mockingbird and Geraldine Brooks's March. Theses and Dissertations Knowledge Repository. Retrieved from .library.iup.edu/etd/1324

Pearson, A. (2018). Charles Hamilton Houston: Mockingbird with talons. Howard Law Journal, 61(2): 319-340. 
Picower, B. (2009). The unexamined Whiteness of teaching: How White teachers maintain and enact dominant racial ideologies. Race Ethnicity and Education, 12(2): 197215.

Pride, R. (2002). The political use of racial narratives: School desegregation in Mobile, Alabama 1954-97. Urbana: University of Illinois Press.

Ramose, M. (2002). The philosophy of ubuntu and ubuntu as a philosophy. In P.H. Coetzee \& A.P.J. Roux (Eds), Philosophy from Africa: A text with readings (pp. 230-237). Cape Town: Oxford University Press.

Reginster, B. (2000). Nietzsche on selflessness and the value of altruism. History of Philosophy Quarterly, 17(2): 177-200.

Ross, T. (1990). The rhetorical tapestry of race: White innocence and black abstraction. William \& Mary Law Review, 32(1): 1-40.

Said, E. (1986). Intellectuals in the post-colonial world. Salmagundi, 70: 44-64.

Sandoval, C. (2000). Methodology of the oppressed. Minneapolis: University of Minnesota Press.

Van Patten, J. (2012). Storytelling for lawyers. South Dakota Law Review, 57: 239-276.

Van Patten, J. (2016). The trial of Tom Robinson. South Dakota Law Review, 61: 5180.

Vera, H., Feagin, J.R. \& Gordon, A. (1995). Superior intellect? Sincere fictions of the white self. Journal of Negro Education, 64(3): 295-306.

Vice, S. (2010). How do I live in this strange place? Journal of Social Philosophy, 41(3): 323-342.

Ward, C. (1994). A kinder, gentler liberalism? Visions of empathy in feminist and communitarian literature. William \& Mary Law School Scholarship Repository, 271.

Wicks, J. (2018, 28 August). English teacher accused of K-word rant. Times Live. Retrieved from https://www.timeslive.co.za/news/south-africa/2018-08-28english-teacher-accused-of-k-word-rant/ 